\title{
Muscle Protein Metabolism in Critically Illness
}

\author{
Min Chang Kang, M.D. \\ Division of General Surgery, Soonchunhyang University Seoul Hospital, Seoul, Korea
}

Most patients experience a considerable amount of muscle wasting during critical care. A decrease in muscle mass causes weakness which inevitably leads to delayed recovery. Since muscle also plays an important role in protein metabolism, metabolic instability increases as muscle mass decreases. Accordingly, various treatments have been attempted to maintain muscle mass and function in critically ill patients; however, it is still difficult to prevent muscle loss. It is known that muscle wasting in critical illness is primarily due to increased muscle protein breakdown rather than a decrease in muscle protein synthesis. Nutritional therapy and rehabilitation are fundamentally important, but additional anabolic agents may be needed to overcome anabolic resistance. In this review, we will learn about muscle protein metabolism in critically ill patients and how various treatments affect muscle protein metabolism.

Keywords: Critical illness, Metabolism, Muscle proteins, Amino acids, Rehabilitation

\section{INTRODUCTION}

Muscle has an essential metabolic role in addition to its ability to move the body and maintain posture.[1] As a part of the whole-body protein pool, skeletal muscle serves as the main reservoir for amino acids and provides hepatic gluconeogenic precursors. [2,3] Therefore, a decrease in muscle mass not only means an impairment of mechanical muscle function but also a reduction in metabolic reserve in stress conditions, such as trauma, burns, or sepsis. Most patients in intensive care units (ICUs) experience muscle wasting. [4] The rate of muscle wasting has been reported to be $1 \sim 6 \%$ of total muscle protein per day in previous studies.[4-6] Combined with critical illness neuropathy, muscle wasting contributes to the development of ICU-acquired weakness.[79] However, the clinical factors that provoke or alleviate the extent of muscle wasting in the ICU are less well investigated. [10] Muscle protein metabolism in critical illness is one of the most relevant research topics in the critical care and nutrition field.

\section{WHOLE-BODY PROTEIN TURNOVER}

For normal adults, the amount of whole-body protein is known to be about approximately $10 \mathrm{~kg}$ (Fig. 1). Daily, 3\% of whole-body protein is recycled.[11] Muscle protein turnover is lower than that in other organs, but since muscle has the largest mass, it accounts for the main portion (33\%) of daily protein turnover. Vital organs, such as the liver and kidneys, show relatively high protein turnover, and the rate of turnover itself could increase in critically ill patients. Organs with high turnover may become vulnerable to a reduction in the availability of amino acids. These findings support recent nutritional guidelines not to reduce protein supply in the acute phases of hepatic and renal failure.[12]

\section{NORMAL MUSCLE PROTEIN BALANCE}

Muscle is a dynamic organ, both mechanically and metabolically. Muscle protein undergoes simultaneous synthesis and breakdown, and the balance between muscle protein synthesis (MPS) and muscle protein breakdown (MPB) determines the net protein balance (NPB).[13] The NPB value can

Received December 14, 2020; Accepted December 17, 2020

Corresponding author: Min Chang Kang

E-mail stserver@naver.com (iD) ORCID https://orcid.org/0000-0002-0834-6060

(c) (9) This is an Open Access article distributed under the terms of the Creative Commons Attribution Non-Commercial License (http://creativecommons.org/licenses/ by-nc/4.0), which permits unrestricted non-commercial use, distribution, and reproduction in any medium, provided the original work is properly cited. 


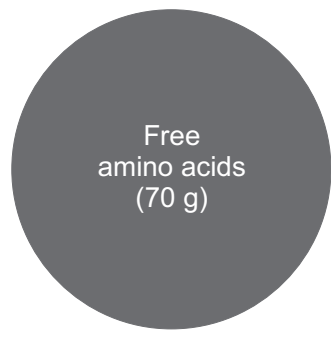

\begin{tabular}{|c|}
\hline Degradation (300 g/day) \\
\hline $\begin{array}{l}\text { Muscle (100 g/day) } \\
: 2 \% / \text { day (turnover rate) }\end{array}$ \\
\hline $\begin{array}{l}\text { Liver (80 g/day) } \\
: 25 \% / \text { day }\end{array}$ \\
\hline $\begin{array}{l}\text { Intestine (60 g/day) } \\
: 20 \% / \text { day }\end{array}$ \\
\hline $\begin{array}{l}\text { Kidney (30 g/day) } \\
\text { : } 30 \% / \text { day }\end{array}$ \\
\hline $\begin{array}{l}\text { Skin and other organs } \\
: 15 \% / \text { day }\end{array}$ \\
\hline $\begin{array}{l}\text { Total ( } 300 \mathrm{~g} / \text { day) } \\
\text { : mean } 3 \% / \text { day }\end{array}$ \\
\hline
\end{tabular}

be obtained by subtracting the MPB from the MPS value. In healthy adults, the turnover rate of muscle protein is reported to be 1 2\% per day.[14] There are alternating periods of positive and negative net protein balance throughout the day. [15] Protein breakdown exceeds synthesis in the fasting state, even in healthy adults.[3] Obligatory oxidation of essential amino acids released into the intracellular space during the fasting period contributes to the negative balance. The amino acids supplied through the following meals replete the loss during the fasting period. As this cycle repeats, the total net protein balance approaches zero and the muscle mass remains constant.

\section{STABLE ISOTOPE TRACER METHOD}

In vivo protein turnover in humans can be measured using the stable isotope tracer method.[13] One or more tracers (e.g., stable isotope-labeled amino acids) are infused intravenously, and the plasma levels of tracers are measured repeatedly to calculate the turnover rate of the tracee (e.g., amino acids of interest). In the steady state, after the continuous infusion of a stable isotope tracer at a constant rate, the blood concentration of the tracer and tracee reaches a certain plateau level. The ratio of tracer to tracee (i.e., isotope enrichment) in the steady state is inversely correlated with the rate of appearance of the tracee in plasma. If the rate of appearance of essential amino acids in the fasting state is determined, we can calculate the rate of degradation of whole-body proteins. Isotope enrichment was determined using gas chromatography and mass spectrometry. Kim et al. [13] reviewed the method of metabolic research with stable isotopes in their article.

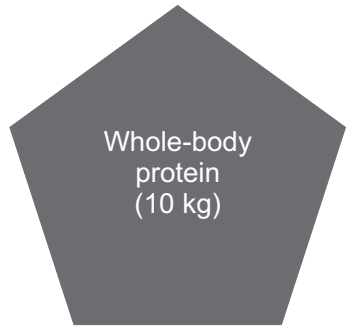

Fig. 1. Whole-body protein turnover.

\section{CRITICAL ILLNESS}

Catabolism dominates metabolism in critically ill patients. Increased MPB, rather than decreased synthesis, leads to muscle wasting. Essential amino acids derived from muscle breakdown are utilized to meet the increased demands for acute-phase protein synthesis, immune function, and wound healing. For example, more than $3 \mathrm{~g} / \mathrm{kg} /$ day of protein, four times the normal daily intake, is required for wound healing of burns affecting $50 \%$ of the body surface area.[16] Contrary to common expectations, MPS is also increased in critical illness. Accelerated MPB provides excess intracellular free amino acids and, in turn, these free amino acids serve as substrates and facilitate MPS.[3] However, even with aggressive nutritional therapy, accelerated MPB is difficult to offset by protein synthesis due to anabolic resistance.[17] The change in each component of muscle protein metabolism in various clinical conditions is summarized in Table 1.

\section{Anabolic resistance}

The mechanisms of anabolic resistance have not been fully investigated, but two possible mechanisms have been suggested. First, the inward transport of essential amino acids into muscle cells is impaired in a critically ill state. Due to this impairment, the supplied amino acids may not exert a sufficient anabolic effect on muscle. Diffusion through the interstitial fluid is the rate-limiting stage for the inward transport of essential amino acids to the muscle cell.[18] The presence of tissue edema, frequently present in critically ill patients, could impede amino acid uptake by muscle cells.[19]

Second, the rates of amino acid efflux from the intracellular space to the plasma and obligatory oxidation of essential 
Table 1. Muscle protein metabolism in various clinical conditions

\begin{tabular}{lccc}
\hline & MPS & MPB & NPB \\
\hline Normal (post-prandial) & ++ & + & + \\
Normal (fasting) & + & +++++ & - \\
Catabolic state (fasting) & +++ & +++++ & -- \\
Catabolic state (protein supply) & ++++ & $?$ & - \\
Catabolic state (rehabilitation) & $?$ & + \\
\hline
\end{tabular}

The number of (+) or (-) signs indicates the relative rate of synthesis or breakdown of muscle protein, respectively. MPS $=$ muscle protein synthesis; $\mathrm{MPB}=$ muscle protein breakdown; $\mathrm{NPB}=$ net protein balance.

amino acids within the intracellular space increase in the catabolic state.[3] As a result, the concentration of essential amino acids required for the re-synthesis of muscle protein is reduced. Regardless of metabolic status, sarcopenia in the elderly is known to be associated with evolving anabolic resistance with aging.[20]

\section{Protein supplement}

In healthy adults, increasing protein supplementation causes a net gain in body protein. Kim et al. [21] proved that when the same amount of calories but different amounts of protein ( $30 \mathrm{~g}$ vs. $70 \mathrm{~g}$ ) are provided, the net protein balance increases proportionally to the amount of protein supplied. Furthermore, essential amino acids are the vital components in stimulating MPS. Volpi et al. [22] showed that if essential amino acid content was equal, the protein synthesis rate was identical, regardless of the non-essential amino acids content. Katsanos et al. [23] showed that there is no increase in protein synthesis when only non-essential amino acids are supplied. Although anabolic resistance exists, the intracellular concentration of amino acids has a linear correlation with protein synthesis, so maintaining a sufficient protein supply in critically ill patients is crucial to improving the net protein balance.[24] Liebau et al. [25] reported that supplying an additional $1 \mathrm{~g} / \mathrm{kg}$ of amino acids to critically ill patients increases MPS but does not affect MPB. In both healthy and critically ill states, the supply of proteins increases protein synthesis but has little effect on protien breakdown.

\section{Rehabilitation}

Due to sedation, bed rest, or weakness most critically ill patients move less, which exacerbates muscle wasting.[26] It is well known that the rate of MPS decreases during immobilization.[27] Although there is not yet definitive evidence, MPB appears to temporarily increase at the beginning of immobilization and then returns to the normal rate as inactivity continues.[28]

There is a growing body of evidence that rehabilitation in critically ill patients is associated with an improvement in clinical outcomes, such as physical function, ventilator-free days, and length of ICU or hospital stay.[29,30] However, few studies have shown that rehabilitation leads to physical improvements in the muscles themselves, such as increasing muscle mass.[10,31] In healthy adults, resistance exercises increase MPS by synergizing with the supply of amino acids. [15] In addition, aerobic exercise enhances the muscle protein anabolic response after nutrient intake in the elderly.[32] Further research is needed to determine whether the benefits of exercise in healthy adults will be equally observed in critical patients. The NEXIS (Nutrition and Exercise in Critical Illness) trial, which will simultaneously evaluate the effects of amino acid supply and rehabilitation in critically ill patients, is in progress.[33] Myostatin, a member of the transforming growth factor- $\beta$ family known to inhibit muscle differentiation and growth, appears to be suppressed and maintained at a low level throughout rehabilitation.[28] MPB may increase with rehabilitation, especially in the early stages, which is known to be related to skeletal muscle remodeling.[34]

\section{Anabolic agent}

Elevated levels of stress hormones, such as catecholamine, cortisol, and glucagon, induce hypermetabolic and catabolic states in critical illness. In this situation, the use of anabolic or anti-catabolic agents, in addition to appropriate nutritional therapy, is theoretically promising. Several potential agents have been studied, including insulin, IGF1/IGFBP-3, propranolol, and androgens (testosterone and oxandrolone).[3538] Interestingly, the metabolic effects of agents often differ from those in normal healthy adults. For example, propranolol, which has no anabolic effect under normal conditions, causes a strong anabolic effect in fed burn patients.[39] Insulin and testosterone exert anabolic effects by inhibiting MPB under normal circumstances, but by increasing MPS in burn patients.[40] Each agent should be used in consideration of their inherent pharmacologic effects and possible adverse reactions.

\section{CONCLUSION}

Muscle is an organ that plays an important role in metabolism and movement. Thus, a decrease in muscle mass causes metabolic instability, as well as weakness, both of which adversely affect clinical outcomes in critically ill patients. Increased muscle protein degradation rather than decreased 
muscle protein synthesis leads to muscle wasting in critical illness, but direct treatment targeting protein breakdown has not been well established. In addition to sustained efforts to increase the supply of protein and provide high-quality rehabilitation, research on clinical factors and treatments to maintain muscle mass in critically ill patients is needed.

\section{CONFLICTS OF INTEREST}

The author of this manuscript has no conflicts of interest to disclose.

\section{ORCID}

Min Chang Kang, https://orcid.org/0000-0002-0834-6060

\section{REFERENCES}

1. Wolfe RR. The underappreciated role of muscle in health and disease. Am J Clin Nutr 2006;84:475-82.

2. Landi F, Camprubi-Robles M, Bear DE, Cederholm T, Malafarina $\mathrm{V}$, Welch AA, et al. Muscle loss: the new malnutrition challenge in clinical practice. Clin Nutr 2019;38:2113-20.

3. Wolfe RR. The 2017 sir David P Cuthbertson lecture. Amino acids and muscle protein metabolism in critical care. Clin Nutr 2018;37:1093-100.

4. Puthucheary ZA, Rawal J, McPhail M, Connolly B, Ratnayake $G$, Chan P, et al. Acute skeletal muscle wasting in critical illness. JAMA 2013;310:1591-600.

5. Reid CL, Campbell IT, Little RA. Muscle wasting and energy balance in critical illness. Clin Nutr 2004;23:273-80.

6. Hickmann CE, Castanares-Zapatero D, Deldicque L, Van den Bergh P, Caty G, Robert A, et al. Impact of very early physical therapy during septic shock on skeletal muscle: a randomized controlled trial. Crit Care Med 2018;46:143643.

7. De Jonghe B, Sharshar T, Lefaucheur JP, Authier FJ, Durand-Zaleski I, Boussarsar $M$, et al.; Groupe de Réflexion et d'Etude des Neuromyopathies en Réanimation. Paresis acquired in the intensive care unit: a prospective multicenter study. JAMA 2002;288:2859-67.

8. Latronico N, Bolton CF. Critical illness polyneuropathy and myopathy: a major cause of muscle weakness and paralysis. Lancet Neurol 2011;10:931-41.

9. Kress JP, Hall JB. ICU-acquired weakness and recovery from critical illness. N Engl J Med 2014;370:1626-35.

10. Puthucheary Z, Denehy L. Chronic critical illness and muscle strength: an ill-defined field. Crit Care Med 2020;48: 1699-701.

11. Attaix D, Boirie Y. Métabolisme protéique. In: Cano N, Barnoud D, Schneider SM, Vasson MP, Hasselmann M, Leverve $X$, eds. Traité de nutrition artificielle de l'adulte. 3rd ed. Paris: Springer, 2007:75-92. French.

12. McClave SA, Taylor BE, Martindale RG, Warren MM, Johnson DR, Braunschweig C, et al.; Society of Critical Care Medicine; American Society for Parenteral and Enteral Nutrition. Guidelines for the provision and assessment of nutrition support therapy in the adult critically ill patient: Society of Critical Care Medicine (SCCM) and American Society for Parenteral and Enteral Nutrition (A.S.P.E.N.). JPEN J Parenter Enteral Nutr 2016;40:159-211.

13. Kim IY, Suh SH, Lee IK, Wolfe RR. Applications of stable, nonradioactive isotope tracers in in vivo human metabolic research. Exp Mol Med 2016;48:e203.

14. Bodine SC. mTOR signaling and the molecular adaptation to resistance exercise. Med Sci Sports Exerc 2006;38:19507.

15. Phillips SM. Protein requirements and supplementation in strength sports. Nutrition 2004;20:689-95.

16. Zhang XJ, Chinkes DL, Cox RA, Wolfe RR. The flow phase of wound metabolism is characterized by stimulated protein synthesis rather than cell proliferation. J Surg Res 2006;135:61-7.

17. Shaw JH, Wildbore M, Wolfe RR. Whole body protein kinetics in severely septic patients. The response to glucose infusion and total parenteral nutrition. Ann Surg 1987;205:288-94.

18. Miller S, Chinkes D, MacLean DA, Gore D, Wolfe RR. In vivo muscle amino acid transport involves two distinct processes. Am J Physiol Endocrinol Metab 2004;287:E136-41.

19. Biolo G, Fleming RY, Maggi SP, Nguyen TT, Herndon DN, Wolfe RR. Inverse regulation of protein turnover and amino acid transport in skeletal muscle of hypercatabolic patients. J Clin Endocrinol Metab 2002;87:3378-84.

20. Tuvdendorj D, Chinkes DL, Zhang XJ, Ferrando AA, Elijah IE, Mlcak RP, et al. Adult patients are more catabolic than children during acute phase after burn injury: a retrospective analysis on muscle protein kinetics. Intensive Care Med 2011;37:1317-22.

21. Kim IY, Schutzler S, Schrader A, Spencer HJ, Azhar G, Ferrando AA, et al. The anabolic response to a meal containing different amounts of protein is not limited by the maximal stimulation of protein synthesis in healthy young adults. Am J Physiol Endocrinol Metab 2016;310:E73-80.

22. Volpi E, Kobayashi H, Sheffield-Moore M, Mittendorfer B, Wolfe RR. Essential amino acids are primarily responsible for the amino acid stimulation of muscle protein anabolism in healthy elderly adults. Am J Clin Nutr 2003;78:250-8.

23. Katsanos CS, Chinkes DL, Paddon-Jones D, Zhang XJ, Aarsland A, Wolfe RR. Whey protein ingestion in elderly persons results in greater muscle protein accrual than ingestion of its constituent essential amino acid content. Nutr Res 2008;28:651-8.

24. Deutz NE, Wolfe RR. Is there a maximal anabolic response to protein intake with a meal? Clin Nutr 2013;32:309-13.

25. Liebau F, Sundström M, van Loon LJ, Wernerman J, Rooyackers $\mathrm{O}$. Short-term amino acid infusion improves protein balance in critically ill patients. Crit Care 2015;19:106.

26. Phillips SM, Dickerson RN, Moore FA, Paddon-Jones D, Weijs PJ. Protein turnover and metabolism in the elderly intensive care unit patient. Nutr Clin Pract 2017;32(1_ suppl):112S-20S.

27. Dideriksen K, Reitelseder S, Agergaard J, Boesen AP, Aas $\mathrm{SN}$, Raastad T, et al. Muscle protein breakdown is impaired during immobilization compared to during a subsequent retraining period in older men: no effect of anti-inflamma- 
tory medication. Pflugers Arch 2020;472:281-92.

28. Ferrando AA, Lane HW, Stuart CA, Davis-Street J, Wolfe RR. Prolonged bed rest decreases skeletal muscle and whole body protein synthesis. Am J Physiol 1996;270(4 Pt 1):E627-33.

29. Kayambu G, Boots R, Paratz J. Physical therapy for the critically ill in the ICU: a systematic review and meta-analysis. Crit Care Med 2013;41:1543-54.

30. Laurent H, Aubreton S, Richard R, Gorce Y, Caron E, Vallat $A$, et al. Systematic review of early exercise in intensive care: a qualitative approach. Anaesth Crit Care Pain Med 2016;35:133-49.

31. Supinski GS, Valentine EN, Netzel PF, Schroder EA, Wang L, Callahan LA. Does standard physical therapy increase quadriceps strength in chronically ventilated patients? A pilot study. Crit Care Med 2020;48:1595-603.

32. Timmerman KL, Dhanani S, Glynn EL, Fry CS, Drummond MJ, Jennings $K$, et al. A moderate acute increase in physical activity enhances nutritive flow and the muscle protein anabolic response to mixed nutrient intake in older adults. Am J Clin Nutr 2012;95:1403-12.

33. Heyland DK, Day A, Clarke GJ, Hough CT, Files DC, Mourtzakis $M$, et al. Nutrition and exercise in critical illness trial (NEXIS Trial): a protocol of a multicentred, randomised controlled trial of combined cycle ergometry and amino acid supplementation commenced early during critical illness. BMJ Open 2019; 9:e027893.

34. Damas F, Phillips SM, Libardi CA, Vechin FC, Lixandrão
$M E$, Jannig PR, et al. Resistance training-induced changes in integrated myofibrillar protein synthesis are related to hypertrophy only after attenuation of muscle damage. J Physiol 2016;594:5209-22.

35. Ferrando AA, Sheffield-Moore M, Wolf SE, Herndon DN, Wolfe RR. Testosterone administration in severe burns ameliorates muscle catabolism. Crit Care Med 2001;29: 1936-42.

36. Wolf SE, Thomas SJ, Dasu MR, Ferrando AA, Chinkes DL, Wolfe RR, et al. Improved net protein balance, lean mass, and gene expression changes with oxandrolone treatment in the severely burned. Ann Surg 2003;237:801-10.

37. Herndon DN, Ramzy PI, DebRoy MA, Zheng M, Ferrando AA, Chinkes DL, et al. Muscle protein catabolism after severe burn: effects of IGF-1/IGFBP-3 treatment. Ann Surg 1999;229:713-20.

38. Ferrando AA, Chinkes DL, Wolf SE, Matin S, Herndon DN, Wolfe RR. A submaximal dose of insulin promotes net skeletal muscle protein synthesis in patients with severe burns. Ann Surg 1999;229:11-8.

39. Herndon DN, Hart DW, Wolf SE, Chinkes DL, Wolfe RR. Reversal of catabolism by beta-blockade after severe burns. N Engl J Med 2001;345:1223-9.

40. Ferrando AA, Sheffield-Moore M, Paddon-Jones D, Wolfe RR, Urban RJ. Differential anabolic effects of testosterone and amino acid feeding in older men. J Clin Endocrinol Metab 2003;88:358-62. 